\title{
粒状要素解析による地盤材料損傷モデルの定式化
}

\section{Formulation of Damage Model for Geomaterials with Granular Element Analysis}

\author{
金子賢治*，岸野佑次 ${ }^{* *}$ ，林 直宏 $* * *$ ，京谷孝史 $* * * *$ \\ Kenji KANEKO, Yuji KISHINO, Naohiro HAYASHI and Takashi KYOYA \\ *学生会員 工修 東北大学大学院工学研究科土木工学専攻（９980-8579 仙台市青葉区荒巻字青葉） \\ **正会員 工博 東北大学教授 大学院工学研究科土木工学専攻（同 上） \\ ***正会員 工修 国際航業 (株) 東北事業本部（テ983-0852 仙台市宮城野区榴岡5-1-23仙台Kビル） \\ $* * * *$ 正会員 工博 東北大学助教授 大学院工学研究科土木工学専攻 (T980-8579 仙台市青葉区荒巻字青葉)
}

\begin{abstract}
The loss of interparticle bonding causes mechanical damage to cohesive geomaterials. The damage model is a constitutive model to obtain a relationship between stress and strain which changes with the degree of damage. The authors developed a simulation model to evaluate the degree of damage in terms of the Granular Element Method. In this model the periodic boundary is adopted to perform element tests with the minimum influence of boundary condition. By a tentative application, it was found that the stress-strain relationship was predicted fairly well even with a simple damage model.
\end{abstract}

Key Words : damage model, geomaterials, periodic boundary control, Granular Element Method

\section{1.はじめに}

材料中に無数に分布する微視的き裂や空隙などの 構造欠陥は, 強度や剛性の低下といった材料損傷の 原因となり，最終的には材料の破断をもたらす。損 傷力学は, このような材料内部に分布している構造 欠陥の力学的効果に着目し, これを連続的な変数場 として記述することにより, 材料中の構造欠陥とこ れを含む材料の力学的挙動を連続体力学の枠内で扱 おうとするものである．損傷力学は，脆性的破壊ク リープ時間を算定することを目的にKachanov ${ }^{11} に$ よって初めて提案されて以来, 主に金属材料を対象 として発展してきた. Kachanovは, 材料損傷を支配 する要因は微視的空隙の発達による有効断面積の減 少であると考え，これを損傷パラメータとして用い た．その後, 金属材料のクリープ現象はもとより延 性・塑性損傷队疲労損傷にも拡張されている ${ }^{2 \vdash 6)}$.

土木工学の分野において，損傷力学はコンクリー トや岩石7), ${ }^{8)}$ などの脆性材料に対して適用されてい る. 特に岩石は地盤材料の内で最も脆性的な材料で あり, 微視的き裂や空隙の発生・発展がその変形に 大きく影響を及ぼすと考えられている。このため, 岩石内部の微視的き裂や空隙を損傷パラメータで表 し,これを内部変数とする損傷力学に基づいた構成 則が頻繁に用いられる。

一方, 粘着力を有する地盤材料の非弾性変形メカ ニズムは，個々の粒子間の結合が失われることに起 因すると考えられる。このような粒子間の結合の峦 失を材料内部の構造欠陥の発展ととらえ, このこと を損傷力学における損傷パラメータの変化として表
すことにより，材料内部の微視的変形機構を反映し た合理的な構成則の定式化を行うことを可能とする であろう。しかし，コンクリートや岩石などの脆性 材料においては, $\mathrm{AE}$ 試験などにより材料内部の微 視的損傷の発展を測定することが行われているが, 粘着性の地盤材料に対して実際の実験などによって 材料内部の微視的損傷の発生・発展を測定すること は非常に困難である。したがって, 地盤材料の巨視 的な挙動のみではなく, その微視的な変形メカニズ ムを解明するためには, 離散的な粒状体モデルによ る載荷シミュレーション試験が一つの有効な手段で あると考えられる. 地盤材料に対する離散的解析手 法 $^{9),}{ }^{10)}$ の一つである粒状要素法 ${ }^{10)}$ は, 粒子の接触状 態より定まる剛性行列を考慮した準静的な解析手法 であり，材料の変化に伴う微視的情報を得るための 有効な手法である。また, 地盤材料の載荷シミュ レーション試験を行うにあたっては，境界条件に左 右されない材料本来の力学特性を抽出する必要があ る。境界条件の影響を受けにくい制御法として周期 境界制御があるが，比較的少ない粒子数で地盤材料 モデルの載荷シミュレーション試験を行うのに適し た制御法である。

本文においては，地盤材料を粘着力により粒子が 結合した粒状体としてモデル化し，この結合が失わ れる過程を損傷と捉えた構成モデルの提示を行っ た. 特に，損傷度を具体的に求めるために新たに開 発した周期境界制御粒状要素法を用いた載荷シミュ レーション試験を実施し，この結果をもとに構成モ デルの妥当性について考察を行った。 


\section{2. 地盤材料の粒状要素モデル}

粒状要素法 ${ }^{10), 11)}$ の剛体粒子や粒子間バネなどを用 いる点に関しては, 地盤材料の離散解析に広く用い られている個別要素法" ${ }^{9}$ と同様である。両者の主な 相違点は, 個別要素法が差分法により粒子の運動を 追跡するのに対して, 粒状要素法は各粒子の接触状 態から定まる全体剛性行列を考慮し，つり合い条件 を満足しながら増分計算を行う点である．また，粒 状要素法がより精度の高い制御を可能とすることや より明確に地盤材料の力学特性を抽出できることが 示されている ${ }^{11)}$. ここでは, 粒状要素法を一般的な 地盤材料の要素試験に応用するために, 粒子間粘着 力と周期境界制御を導入する方法について示す.

周期境界とは，単位の粒子集合体を上下左右に繰 り返して得られる無限の粒子集合を取り扱う境界制 御法であり，その解析結果は，周期的な特性をもつ が無限に広がる材料本来の力学特性に近い性質を得 ることができる。周期境界制御は, 境界条件の影響 をなるべく排除し, 材料本来の力学特性の把握を目 的としており, 信頼度の高い微視的情報に基づく構 成則の検証に適した手法である.

また，粒子間接触点に粘着力を導入する理由は， 粒状要素法をより一般的な地盤材料への適用を可能 とするためである．粘着力を 0 とすることにより従 来の粒状要素法と同様に砂を対象とすることもで き, 粘着力を非常に強くすれば軟岩なども解析の対 象とすることができよう。また，粘土については両 者の中間の粘着力を持たせることにより解析を可能 とする．粒子間の粘着力には，一般にサクション力 も含まれるが, 本論文では, 砂岩のように圧縮力を 受けて粒子同士が互いに結合したような地盤材料を 対象とする。したがって，ここでは初期状態におけ る結合力を粘着力と考方，この粘着力が失われた後 の力学的相互作用は摩擦力のみと考えてモデル化を 行った.

\section{1 粒子のモデル化と損傷テンソルの算定}

粒子間接触点のモデル化は，接触点に粘着力が作 用し粒子同士が結合している場合と粘着力が作用せ ず粒子同士の結合が解消された場合とに分ける必要 がある。

粒子間に粘着力が作用している場合, 粒子間に図1に示すような仮定を設ける. 砂や土粒子を表す 2 次 元剛体円形粒子とその接触点にバネ要素, テンショ ンカットオフ要素, 摩擦性要素を仮定する。テン ションカットオフ要素を設けることにより，粒子間 に想定したバネ要素はある程度の引張り力（負の符 号とする）にも抵抗することとなる。ささらに，粒子 間に働く引張り力が仮定した粒子間粘着力を超えた ときに粒子間の結合が解消されるものとする。ま
た，接線方向成分に対してはCoulombの摩擦則を考 慮する，以上の粒子間結合条件は，次式のように表 される。

$$
\left\{\begin{array}{lll}
\sqrt{p_{n}{ }^{2}+p_{t}^{2}} \leq c & \text { if } & p_{n}<0 \\
\left|p_{t}\right| \leq p_{n} \tan \phi+c & \text { if } & p_{n} \geq 0
\end{array}\right.
$$

ここに,

$p_{n}$ : 接触点における接触力の法線方向成分

$p_{t}$ : 接触点における接触力の接線方向成分

$\phi$ : 粒子間摩擦角

$c$ : 粒子間粘着力

である。ここでは，前述のように粒子間の粘着力が 水などの影響によるものではなく粒子同士が粘着力 により結合した地盤材料を対象としているため，式 (1)の条件を満たし粒子同士が結合している場合には 粒子間にすべりは生じないものとし，載荷途中に新 たに生成した接触点には粘着力は生じないものと仮 定する.

初期状態における全ての接触点は結合しているも のとし, 載荷が進み粒子間の結合が解消された接触 点においては図-1に示すテンションカットオフ要素 がノーテンション要素のように働き，引張りに対し て抵抗しないこととなる。この後，以下のすべり発 生条件を満たすと粒子間接触点においてすべりが生 ずることとする。

$$
\left|p_{t}\right| \geq p_{n} \tan \phi
$$

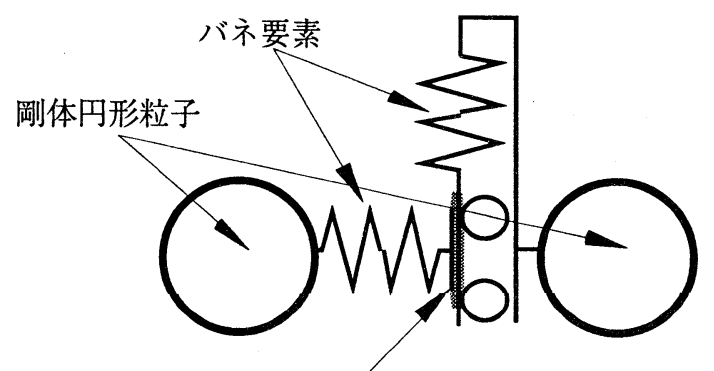
テンションカットオフ（ノーテンション）要素 摩擦性要素

図-1＼cjkstart粒子間力学特性モデル

結合が裚失した粒子間接触点

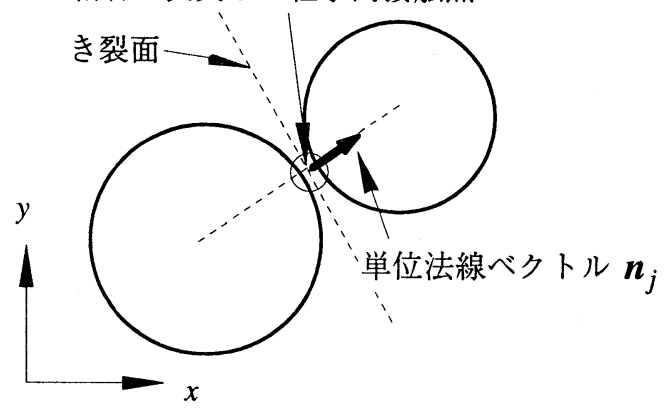

図-2 き裂面の単位法線ベクトル 
粘着力を考慮した粒状要素法による載荷シミュ レーション試験を行うと, 粒子間接触点の状態から 構造欠陥の分布を観察することができ，これらの構 造欠陥の分布情報から材料の損傷を定量的に評価す ることが可能となる．損傷パラメータについては 様々な定義が考えられるが, ここでは，欠陥の方向 とその大きさの情報を表すことのできる 2 階の損傷 テンソルを例示する.

粘着力により結合していた粒子Aと粒子B の接触 力が式(1)の結合条件を超えて, 粒子 $\mathrm{A}$ と粒子Bが剥 離するとする。粒子 $\mathrm{A}$ と粒子 $\mathrm{B}$ の間に発生するき裂 面は，それぞれの粒子の中心を結ぶ線に対し垂直で あり，このき裂面をその単位法線べクトルで表すこ とができる。対象領域中の $j$ 番目のき裂の単位法線 ベクトルを $\boldsymbol{n}_{\boldsymbol{j}}$ (図-2）, 初期状態で結合していた総 接触点数を $N$ とし, 損傷テンソル $D$ を次式で定義 することとする。

$$
D=\sum_{j} \frac{1}{N} n_{j} \otimes n_{j}
$$

式(3)はKachanov ${ }^{1)}$ 損傷パラメータに対応したもの である。

粘着力を考慮した粒状要素モデルの解析アルゴリ ズムは, 従来のアルゴリズム ${ }^{11}$ において粒子間の力 学特性を変更する点が異なるのみである.

\section{2 周期境界制御法}

材料の構成則の検証を実際に要素試験で行う場合 に問題となるのは, 供試体の境界の影響である。こ れは，現実の試験においても共通したことである が，例えば，端面拘束の影響が供試体内部の応力分 布の不均一性を生じさせるなど, 本来材料試験とし て望ましくない要因をなるべく避けることが重要で ある．従来の粒状体載荷シミュレーション試験にお いても内部粒子は外部粒子あるいは外壁によって制 御されるため, 多かれ少なかれ境界の影響を受ける ことになる。そこで，周期境界制御法を用いること により，周期性という制約はあるが解析対象モデル を無限に広がった領域とみなすことができ，比較的 少ない粒子数でも理想に近い状態を実現することが できる，ただし，例えば変形局所化の研究のよう な, 境界条件に依存する变形解析には馴染まないこ とに留意する必要がある。ここでは，材料自身のも

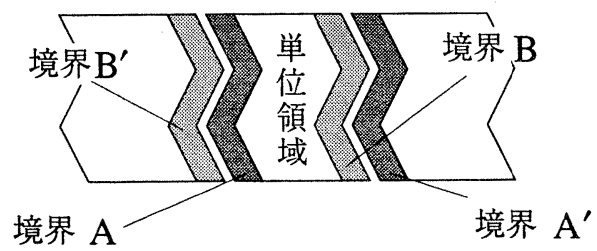

図-3 1 次元周期境界の概念
つ力学特性を解明するために開発した粒状要素法の 周期境界制御法について述べる. 粒状要素法の周期 境界制御においては, 後述する周期長, せん断長の 変化を剛性関係に基づいて制御することが特徴であ る.

\section{(1) 周期境界の考え方}

図-3において境界 A，Bを単位領域の左右方向に 対をなす境界とする. 各々の境界の外側にこの単位 領域が繰り返し配置されているとすると, 左右方向 に無限に続く領域を想定することができる．同様 に，上下方向に展開すれば，単位領域が二次元的に 無限に続く領域を想定することができる。周期境界 制御を用いると，単位領域を解析することにより， 無限に続く領域の解が得られ, 境界条件に支配され ない材料本来の力学特性を解明することができる.

ここで，周期境界上の境界粒子の取り扱いについ て述べる. 図-3のような周期境界を実現するために 図-4に示すように，周期境界において境界外側にダ ミ一粒子を配置する，同図のように粒子 $n$ と粒子 $m$ はそれぞれ $x$ 方向に対をなす境界に接している。粒 子 $n$ に接触している粒子 $m$ のダミー粒子を $m^{\prime}$, 粒 子 $m$ に接触している粒子 $n$ のダミー粒子を $n^{\prime}$ とし, 各粒子の中心座標をそれぞれ $\left(x_{n}, y_{n}\right),\left(x_{m}, y_{m}\right)$ と する $\left(x_{n}<x_{m}\right)$. また, 図-5に示すように, 変形 後の周期境界の $x, y$ 方向長さ(これを周期長と称 する）を $s_{x}, s_{y}$ ，せん断によるずれ（これをせん断 長と称する）を $t_{x y}, t_{y x}$ とすれば，粒子 $m^{\prime}$ の中心座 標は $\left(x_{m^{\prime}}, y_{m^{\prime}}\right)=\left(x_{m}-s_{x}, y_{m}-t_{x y}\right)$, 粒子 $n^{\prime}$ の中心

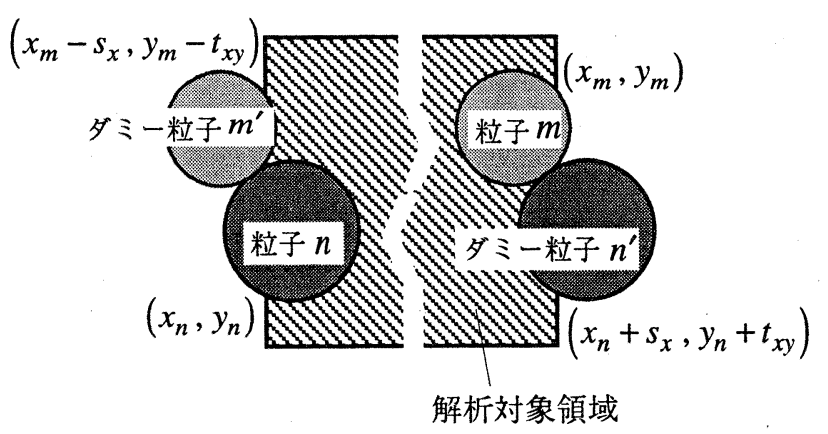

図-4 境界粒子とダミー粒子

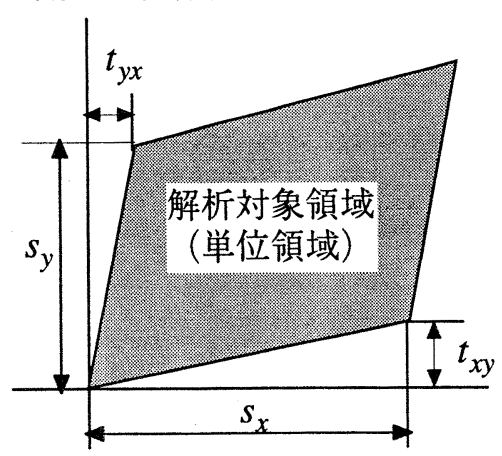

図-5 周期長とせん断長さ 
座標は $\left(x_{n^{\prime}}, y_{n^{\prime}}\right)=\left(x_{n}+s_{x}, y_{n}+t_{x y}\right)$ となる。これら の中心座標加粒子 $n$ と粒子 $m^{\prime}$, 粒子 $m$ と粒子 $n^{\prime}$ の接触力と接触関係を求めることにより, 従来の粒 状要素法 ${ }^{10), 11)}$ と同様のアルゴリズムにより解析を行 うことができる。

\section{（2）応力，ひずみの算定法と制御法}

境界粒子がダミー粒子から受ける力は解析対象領 域の境界が外部から受ける力であるとみなすことが できる．第 1 Piola-Kirchhoff応力を用いることとす れば, 各境界粒子の初期座標 $\left(X_{0}, Y_{0}\right)_{\mathrm{B}}$, 各境界粒子 が各ダミ一粒子から受ける力の合力 $\left(f_{x}, f_{y}\right)_{\mathrm{B}}$, 対象 領域の初期面積 $A_{0}$ より, 応力は次式で与えること ができる。

$$
\left[\begin{array}{ll}
\sigma_{x} & \tau_{x y} \\
\tau_{y x} & \sigma_{y}
\end{array}\right]=\frac{1}{A_{0}} \sum_{\mathrm{B}}\left[\begin{array}{cc}
f_{x} X_{0} & f_{y} X_{0} \\
f_{x} Y_{0} & f_{y} Y_{0}
\end{array}\right]
$$

$\sigma_{x}, \sigma_{y}$ は垂直応力, $\tau_{x y}$ はせん断応力であり, 添 字Bは境界粒子を意味する。

また，初期状態の周期長を $x$ 方向， $y$ 方向それぞ れ $s_{0 x}, s_{0 y}$ とするとひずみは次式で表される.

$$
\left[\begin{array}{cc}
\varepsilon_{x} & \frac{\gamma_{x y}}{2} \\
\frac{\gamma_{x y}}{2} & \varepsilon_{y}
\end{array}\right]=\left[\begin{array}{cc}
1-\frac{s_{x}}{s_{0 x}} & \frac{1}{2}\left(\frac{t_{x y}}{s_{0 x}}+\frac{t_{y x}}{s_{0 y}}\right) \\
\frac{1}{2}\left(\frac{t_{x y}}{s_{0 x}}+\frac{t_{y x}}{s_{0 y}}\right) & 1-\frac{s_{y}}{s_{0 y}}
\end{array}\right]
$$

$\varepsilon_{x}, \varepsilon_{y}$ は伸縮ひずみ, $\gamma_{x y}$ はせん断ひずみである.

解析対象領域をひずみで制御する場合，ひずみの 目標值を式(5)の左辺に代入し, 周期長, せん断長を 求め，それらを固定して収束するまで逐次計算す る. 応力で制御する場合は, 現応力值と目標応力値 の差を解消するように, 逐次計算途中で周期長, せ ん断長を変化させる必要がある. 現応力值と目標応 力值の差を $\Delta \sigma_{x}, \Delta \tau_{x y}, \Delta \tau_{y x}, \Delta \sigma_{y}$ とすると, 応力が 目標値に達するために境界に加わるべき力の増分 $\Delta F_{x}, \Delta F_{x y}, \Delta F_{y x}, \Delta F_{y}$ は次式で表される.

$$
\left[\begin{array}{cc}
\Delta F_{x} & \Delta F_{x y} \\
\Delta F_{y x} & \Delta F_{y}
\end{array}\right]=\left[\begin{array}{cc}
s_{0 x} & 0 \\
0 & s_{0 y}
\end{array}\right]\left[\begin{array}{cc}
\Delta \sigma_{x} & \Delta \tau_{x y} \\
\Delta \tau_{y x} & \Delta \sigma_{y}
\end{array}\right]
$$

$x$ 方向, $y$ 方向それぞれの境界粒子とダミー粒子の 接触点の合計を $K_{x}, K_{y}$ とすると, 周期長とせん断 長の変化量 $\Delta s_{x}, \Delta t_{y x}, \Delta t_{x y}, \Delta s_{y}$ は次式により求める ことができる。

$$
\left[\begin{array}{l}
\Delta s_{x} \\
\Delta t_{x y} \\
\Delta t_{y x} \\
\Delta s_{y}
\end{array}\right]=\left[\begin{array}{llll}
\frac{1}{K_{x} c_{n}} & \frac{1}{K_{x} c_{t}} & \frac{1}{K_{y} c_{t}} & \frac{1}{K_{y} c_{n}}
\end{array}\right]\left[\begin{array}{c}
\Delta F_{x} \\
\Delta F_{x y} \\
\Delta F_{y x} \\
\Delta F_{y}
\end{array}\right]
$$

ここに， $c_{n} ， c_{t}$ は接触点における法線および接線方 表-1＼cjkstart載荷シミュレーション試験に用いた諸

\begin{tabular}{|c|c|}
\hline 粒子数 & 475 (個) \\
\hline 粒径 & $0.05 \sim 0.15(\mathrm{~cm})$ \\
\hline バネ定数法線方向成分 & $1000(\mathrm{kgf} / \mathrm{cm})$ \\
\hline バネ定数接線方向成分 & $700(\mathrm{kgf} / \mathrm{cm})$ \\
\hline 粒子間摩擦角 & $45^{\circ}$ \\
\hline 粒子間粘着力平均值 & $5.0(\mathrm{kgf})$ \\
\hline 初期拘束圧 & $10.0\left(\mathrm{kgf} / \mathrm{cm}^{2}\right)$ \\
\hline
\end{tabular}

向のバネ定数である。このように, 周期境界制御で は応力制御，ひずみ制御に関わらず，間接的に周期 長とせん断長で制御されていることになる。

\section{3. 地盤材料の載荷シミュレーション試験}

本章では, 前章で示した地盤材料の粒状要素モデ ルを用いて行った載荷シミュレーション試験の例を 示す.

\section{1 載荷シミュレーション試験の概要}

単位領域の初期形状は一辺 $5.0 \mathrm{~cm}$ の正方形領域と する. 解析に用いた粒子数やバネ定数などの諸定数 を表-1に示す。周期境界の初期周期長 $s_{0 x}, s_{0 y}$ は, 解析領域が初期に受ける拘束圧による補正長 $a$ を差 し引いた $5.0-a \mathrm{~cm}$ とし, 初期せん断長は 0 とす る.この状態から出発し, 粘着力を 0 として等方圧 が $10.0 \mathrm{kgf} / \mathrm{cm}^{2}$ になるまで等方応力を加え, この 時点で接触している粒子間接触点に粘着力を与え る。この過程は, 砂粒子同士がある拘束圧の下で結 合し砂岩を形成する過程に類似している。なお，載 荷シミュレーション試験の途中で新たに発生した接 触点は粘着力をもたないものとする. 粘着力の大き さは，実材料に応じて定めるべきではあるが，本研 究では平均值が $5.0 \mathrm{kgf}$ となるようにランダムに与 えることとし,このようにして求めた初期状態を図6に示す。同図には，周期境界制御の様子を表すた め, 対象領域の外側の粒子も示した。同図の白色の 粒子が単位領域を形成する粒子である。

以下に示す例は, ひずみ增分を $d \varepsilon_{1}=-0.007071 \%$, $d \varepsilon_{2}=0.007071 \%$ とする周期境界ひずみ制御二軸せ ん断試験であり，ひずみのノルム

$$
\|\boldsymbol{\varepsilon}\|=\sqrt{\varepsilon_{i j} \varepsilon_{i j}}
$$

が3.0\%に達するまで載荷した後，ひずみ増分を反 転させ初期状態まで除荷する。

\section{2 載荷シミュレーション試験結果と考察}

載荷シミュレーション試験では, 載荷途中や載荷 後の材料内部の粒子の移動やすべり, 粒子間接触力 の状態，粘着力を喪失した点の分布などを観察する 


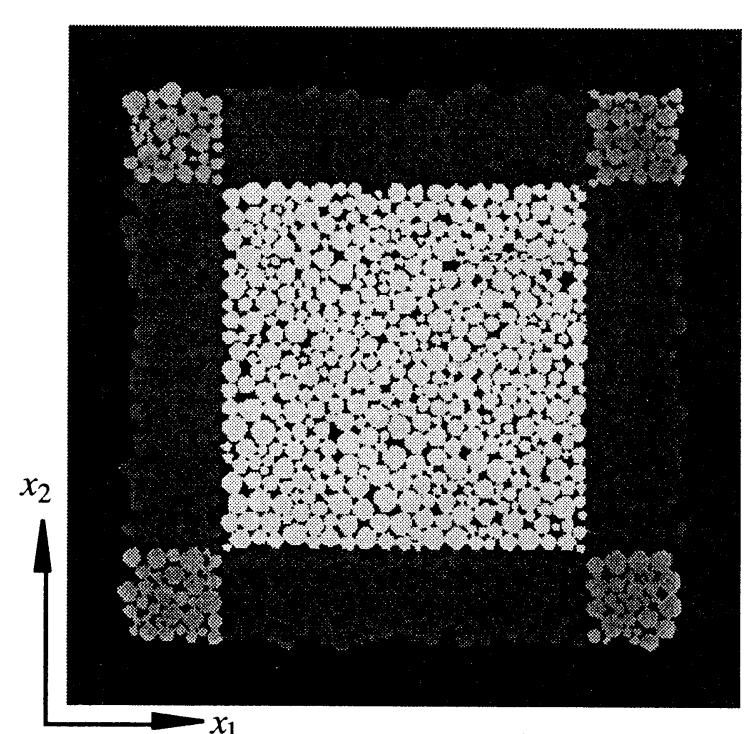

図-6 地盤材料解析モデルの初期状態

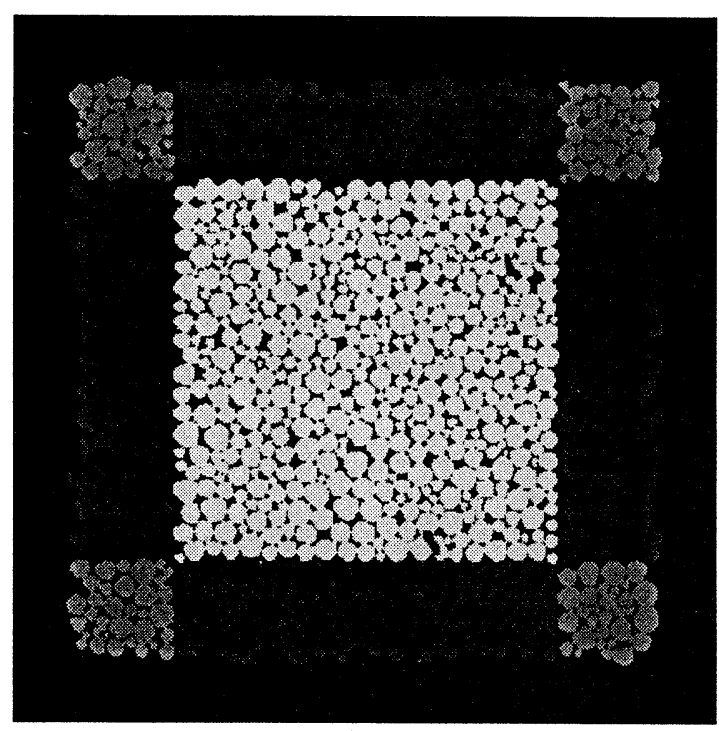

(a) $\|\varepsilon\|=0.8 \%$

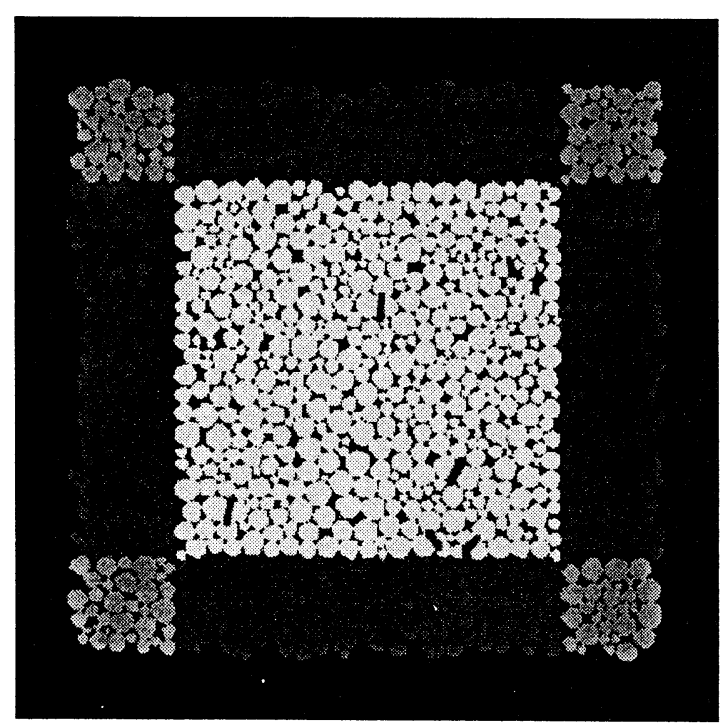

(b) $\|\varepsilon\|=1.4 \%$

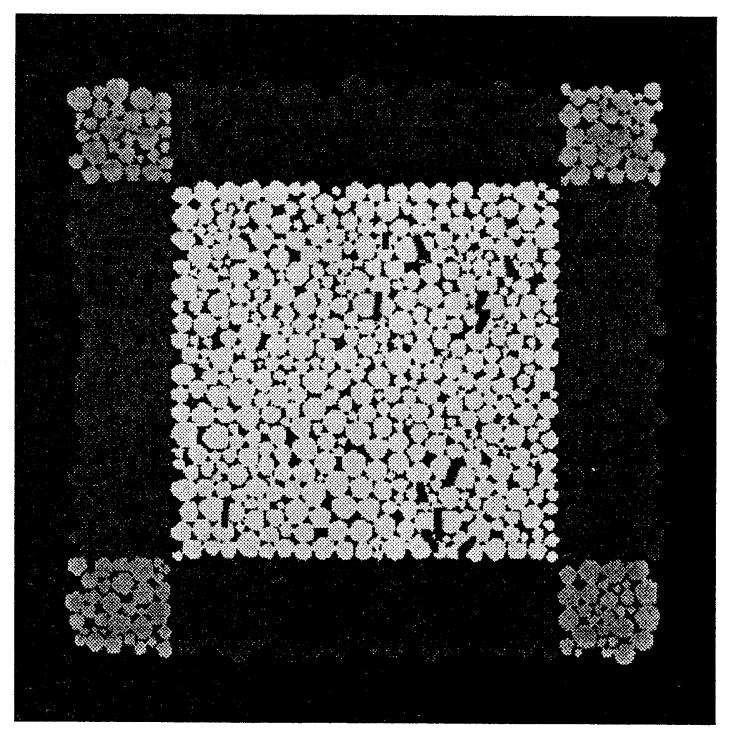

(c) $\|\varepsilon\|=2.0 \%$

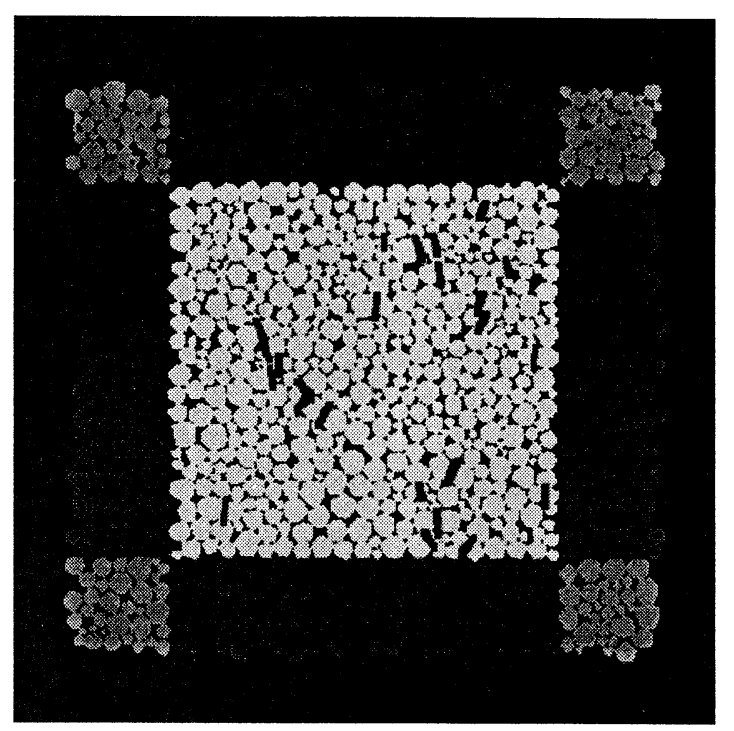

(d) $\|\varepsilon\|=2.6 \%$

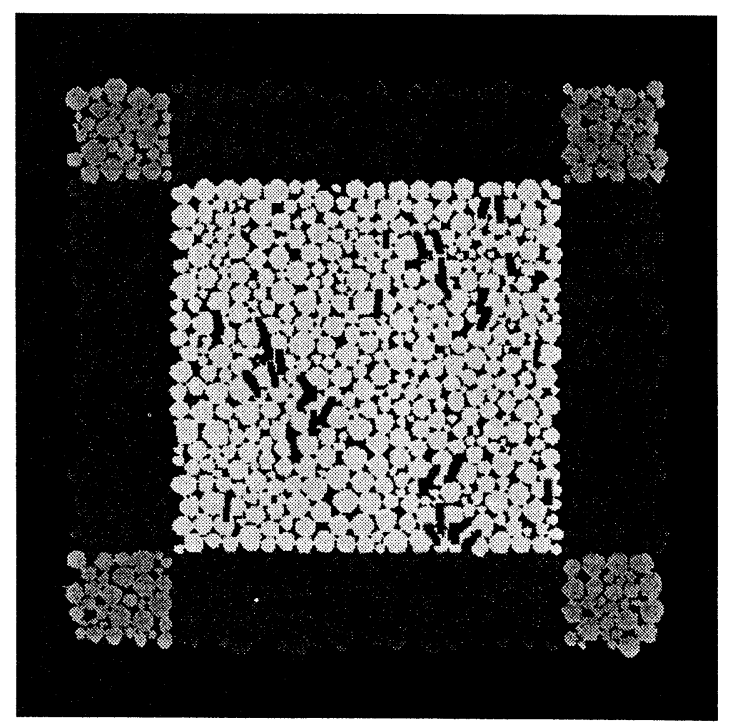

(e) $\|\varepsilon\|=3.0 \%$

図-7き裂分布の変化 
ことができる．粒子の移動と粒子間のき裂分布の変 化の様子を図-7に示すが, き裂面を灰色の線で示し た．図-7より，載荷が進むにつれてき裂の数が増加 することが観察される，また，特に変形局所化など は見られない。

式(3)に示した 2 階の損傷テンソルと $\|\boldsymbol{\varepsilon}\|$ の関係を 図-8に示す．図-8と図-7を比較することにより実際 に生じているき裂とそれを定量的に評価する損傷テ ンソルの変化を観察することができる。図-7, 図-8

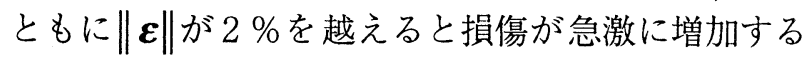
ことが観察される。ささらに，図-7よりき裂面が $x_{2}$ 方 向に多く発生していることがわかり，それに対応し て図-8より，き裂面の単位法線べクトルにより定義 した損傷テンソルの11成分が卓越していることがわ かる. したがって, 解析対象モデルの微視的なき裂 が引張りに対してより多く発生し, 損傷は異方的に 生じるといえるであろう。

また，図-8より，ひずみの増加に伴う損傷テンソ ル各成分の変化の様子がわかるが, 非対角成分は常 にほぼ0であり損傷テンソルの主軸がひずみの主軸 とほぼ一致していることがわかる。また，除荷時に はほとんど損傷の増加は見られない. Kachanov ${ }^{1)}$ 以 来, 損傷パラメータは微視欠陥を代表する物理的 . 力学的に意味をもつ量と考えられてきたが，これを 具体的に構成則に導入する段階においては理論式の 係数をカーブフィッティング的に求める際の変量パ

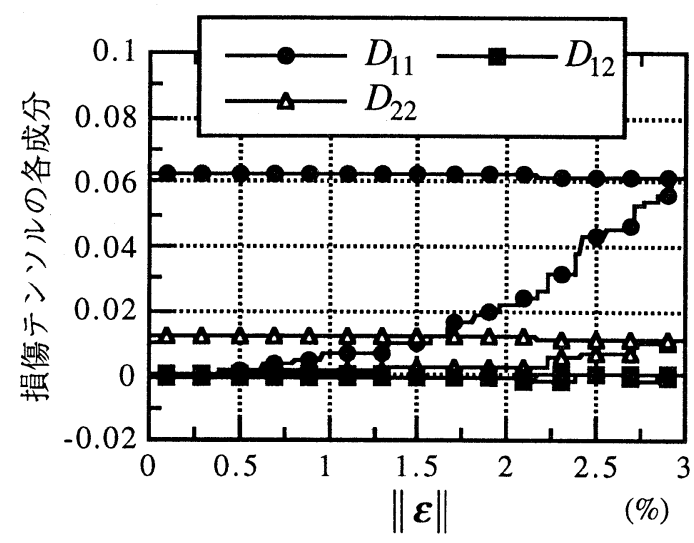

図-8＼cjkstart損傷テンソルの変化

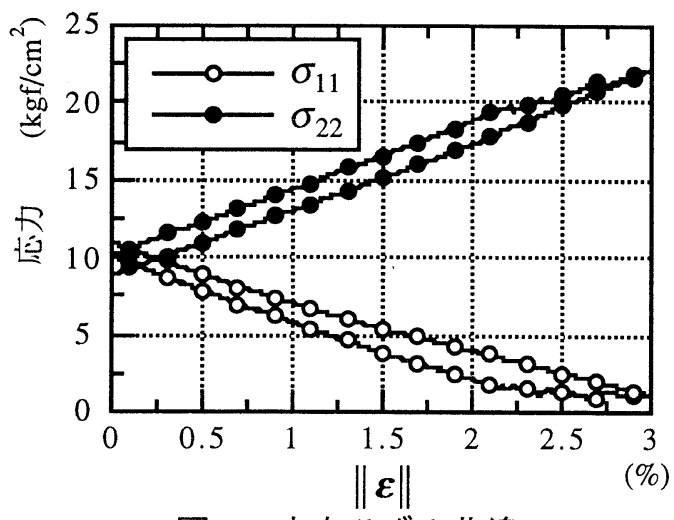

図-9 応力ひずみ曲線
ラメータとして位置づけられているに過ぎない。し たがって，損傷パラメータの值が実際に材料内部の 損傷の様子を具体的に表現しているという保証はな い。これに対して，図-7，8のように，粒状要素法 による載荷シミュレーション試験を用いれば, 粒子 間の結合が解消された接触点（き裂）により定義さ れた損傷パラメータにより, 材料内部の損傷の変化 の様子を具体的に把握することが可能となる。

図-9に, 載荷シミュレーション試験により得られ た応力ひずみ曲線を示す。図中の $\sigma_{11}, \sigma_{22}$ は, 応 カテンソルの11成分，22成分を表すが，主軸の回転 が少ないものとし, 本文ではこれらを主応力とみな すこととする. 図-9と図-8を比較すれば，損傷テン ソルの変化と応力ひずみ曲線の変化との相関関係が わかる. $\|\boldsymbol{\varepsilon}\|$ が約 $2 \%$ で応力ひずみ曲線は急激に傾 き始めるが, 損傷テンソルの各成分も同様に急激に 増加している， $\sigma_{11}$ が $\sigma_{22}$ に比べ傾きが激しいが, 損傷テンソルの 11 成分が 22 成分に比べ大きいことか らも納得できる結果である。本解析においては，1 方向に引張りひずみを与え，2 方向に圧縮ひずみを 与えているが, 損傷の発生は引張りモードにより生 ずるものが大半であるので, 粒子間の結合が解消さ れた接触点情報より定められる損傷テンソルの11成 分は22成分より卓越している。したがって，巨視的 にも 1 方向により大きな非弾性変形が生じるものと 考えられる。

以上より, 本研究で開発した粒状要素モデルの周 期境界制御法は, 地盤材料自身の变形挙動の解析を 可能にするとともに, 境界条件に依存しない微視的 変形機構の解明や材料内部の損傷の観察を行う上で 有効な解析手法であるといえるであろう.

\section{4. 損傷モデルの定式化とその検証}

ここでは, 前章の載荷シミュレーション試験結果 に基づき粘着力を有する地盤材料の損傷モデルを定 式化し，その検証を行う。粘着力を有する地盤材料 の非弾性変形のメカニズムは, 粒子間接触点の結合 の解消とその後の粒子間の摩擦を伴うすべりに支配 されると考えられる，そこで，本文で用いる損傷モ デルは損傷パラメータと塑性ひずみを組み合わせた モデルとし，接触点の結合の解消を損傷パラメータ で表し，粒子間のすべりを塑性ひずみで表すことと する。

\section{1 熱力学に基づく損傷モデル12)}

\section{(1) 一般理論}

Kachanov $^{11}$ により初めて提案された損傷パラメー 夕は, 微視き裂や微視的空隙の発生・発展によって 内力を伝達する面積が減少し, 弾性係数が低下する ことを表す内部パラメータである，損傷パラメータ 
のテンソル特性に関しては，表すべき物理量に関連

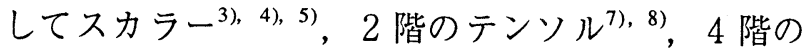
テンソル(13)などが用いられる。ここでは，なるべく 簡単なモデルとするために，式(3)で定義される損傷 テンソル $D_{i j}$ の大きさ $\sqrt{D_{i j} D_{i j}}$ を損傷パラメータ $d$ と して用いることとした。損傷パラメータ $d$ は, 初期 状態で結合していた接触点数に対する載荷途中に結 合が解消された接触点数の比を表しており，損傷を 考慮する上で第 1 に重要な量であるといえる。 $\Delta S$ を損傷を受けた材料内部の任意の面とすれば，内力 を受ける真の面積（有効断面）は $(1-d) \Delta S$ とな る.したがって， $0 \leq d \leq 1$ であり， $d=0$ は損傷を 受けていない初期状態を表し,$d=1$ は完全に損傷 した状態を表す。また，有効断面 $(1-d) \Delta S$ に働く 応力を実質応力 $\bar{\sigma}_{i j}$ と呼び, 応力テンソル $\sigma_{i j}$ と損傷 パラメータ $d$ を用いて次式のように定義する。

$$
\bar{\sigma}_{i j}=\sigma_{i j} /(1-d)
$$

損傷パラメータ $d$ がスカラー量であるので，損傷は 等方的に起こると仮定することになる，以下，スカ ラー損傷パラメータと塑性ひずみを組み合わせた損 傷モデルの一般理論を示す。

まず, 自由エネルギー関数 $W$ を弾性ひずみ $\varepsilon_{i j}^{e}$, 損傷パラメータ $d$, 硬化パラメータ $\beta$ の関数として 次式のように書く.

$$
W=W\left(\varepsilon_{i j}^{e}, d, \beta\right)
$$

弾性ひずみに関して自由エネルギー関数 $W$ と熱力 学的に対をなすGibbsの自由エネルギー関数 $G$ を Legendre変換を用いて次式のように定義する.

$$
G=G\left(\sigma_{i j}, d, \beta\right)=-W+\sigma_{i j} \varepsilon_{i j}^{e}
$$

弾性的な変数と非弾性的な変数に分離可能ならば, 式(9)は次式のように書くことができる。

$$
G=G_{e}\left(\sigma_{i j}, d\right)+G_{p}(\beta)
$$

したがって, 状態方程式は以下のようになる.

$$
\varepsilon_{i j}^{e}=\partial G_{e} / \partial \sigma_{i j}, \quad Y=-\partial G_{e} / \partial d, \quad B=-\partial G_{p} / \partial \beta
$$

ここで，YおよびBは，運動学的变数である損傷パ ラメータ $d$ おひび硬化パラメータ $\beta$ に対する一般化 力である, 特に, $Y$ は一般にエネルギー解放率と呼 ばれる。

また, 散逸ポテンシャル $\varphi$ を降伏関数 $f$ と損傷関 数 $\varphi_{\mathrm{dam}}$ を用いて,

$$
\varphi\left(\sigma_{i j}, B, Y, d\right)=f\left(\sigma_{i j}, \beta, d\right)+\varphi_{\mathrm{dam}}(Y, d) \geq 0
$$

と仮定する。載荷が進んで降伏基準

$$
f\left(\sigma_{i j}, B, d\right)=0
$$

に達すると，損傷と塑性ひずみが同時に発生するこ ととする，実際には，粒子間のすべりは粒子間の結 合が解消された後に発生すると考えられるが, ここ ではその差はわずかであるとし，同時にすべりが発 生するとした.
垂直性の条件より塑性ひずみ，硬化パラメータ， 損傷パラメータの各発展式は次式のように書くこと ができる ${ }^{12)}$.

$$
\begin{aligned}
& \dot{\varepsilon}_{i j}^{p}=\dot{\lambda} \frac{\partial \varphi}{\partial \sigma_{i j}}=\dot{\lambda} \frac{\partial f}{\partial \sigma_{i j}} \\
& \dot{\beta}=\dot{\lambda} \frac{\partial \varphi}{\partial B}=\dot{\lambda} \frac{\partial f}{\partial B} \\
& \dot{d}=\dot{\lambda} \frac{\partial \varphi}{\partial Y}=\dot{\lambda} \frac{\partial \varphi_{\mathrm{dam}}}{\partial Y}
\end{aligned}
$$

さらに, 塑性乗数 $\dot{\lambda}$ は, 適応の条件

$$
\dot{f}=\frac{\partial f}{\partial \sigma_{i j}} \dot{\sigma}_{i j}+\frac{\partial f}{\partial B} \dot{B}+\frac{\partial f}{\partial d} \dot{d}=0
$$

と式(10)拉よび式(11) (13)より，次式のように求 められる。

$$
\dot{\lambda}=-\frac{\partial f}{\partial \sigma_{i j}} \dot{\sigma}_{i j} /\left(\left(\frac{\partial f}{\partial B}\right)^{2} \frac{\partial B}{\partial \beta}+\frac{\partial f}{\partial d} \frac{\partial \varphi_{\mathrm{dam}}}{\partial Y}\right)
$$

以上より, Gibbsの自由エネルギー関数 $G$, 降伏関 数 $f$, 損傷関数 $\varphi_{\mathrm{dam}}$ を仮定すれば, 構成則が確定 する。

\section{(2) 地盤材料の損傷モデル}

ここでは，上述した損傷モデルの一般理論に具体 的な関数を与えて, 図-6で示した地盤材料解析モデ ルに適用する。

まず, Gibbsの自由エネルギー関数 $G$ の弾性的な 変数に関する部分 $G_{e}$ を $E, v$ をヤング率とポアソ ン比として次式のように仮定する。

$$
G_{e}\left(\sigma_{i j}, d\right)=\frac{1}{2(1-d)}\left[\frac{1+v}{E} \sigma_{k l} \sigma_{k l}-\frac{v}{E}\left(\sigma_{k k}\right)^{2}\right]
$$

これは，弾性ひずみ $\varepsilon_{i j}^{e}$ と式(8)で定義した実質応力 $\bar{\sigma}_{i j}$ の関係が等方線形弾性体の構成則と一致するよ うに定めた。つまり，式(10)届用いれば，

$$
\varepsilon_{i j}^{e}=\frac{1+v}{E} \bar{\sigma}_{i j}-\frac{v}{E} \bar{\sigma}_{k k} \delta_{i j}
$$

となる。また,

$$
\varepsilon_{i j}^{e}=\frac{1}{1-d}\left[\frac{1+v}{E} \sigma_{i j}-\frac{v}{E} \sigma_{k k} \delta_{i j}\right]
$$

と書き直せば，損傷を受けることにより材料の弾性 係数が減少しているとみなすこともできる. 同様に 式(10) 2 より，エネルギー解放率は，

$$
Y=-\frac{1}{2(1-d)^{2}}\left[\frac{1+v}{E} \sigma_{k l} \sigma_{k l}-\frac{v}{E}\left(\sigma_{k k}\right)^{2}\right]
$$

となる。

また, Gibbsの自由エネルギー関数 $G$ の非弾性的 な変数に関する部分 $G_{p}$ を $C_{1}, C_{2}$ を係数として次式 のように表す。

$$
G_{p}(\beta)=-\left(\frac{1}{2} C_{1} \beta^{2}+\frac{1}{3} C_{2} \beta^{3}\right)
$$

式(10) 3 を用いれば, 


$$
B=-\frac{\partial W_{p}}{\partial \beta}=C_{1} \beta+C_{2} \beta^{2}
$$

となる。

次に，損傷を考慮したDrucker-Prager型の降伏関 数を次式のように仮定する.

$$
f\left(\sigma_{i j}, B, d\right)=\left(\sigma_{\mathrm{Y}}+C_{3} \sigma_{k k}+B\right) /(1-d)+C_{4}(20)
$$

ここに,

$$
\begin{array}{ll}
\sigma_{\mathrm{Y}}=\sqrt{\sigma_{i j}^{d} \sigma_{i j}^{d}} & \\
\sigma_{i j}^{d}=\sigma_{i j}-p \delta_{i j} & : \text { 偏差応力 } \\
p=\frac{1}{2} \sigma_{k k} & : \text { 2 次元の平均応力 } \\
C_{3}, C_{4} & : \text { 係数 }
\end{array}
$$

である。初期の降伏基準は損傷 $d$ がまだ 0 であるの で一般のDrucker-Prager型の降伏基準と一致する.

最後に，損傷の発展を支配する関数である損傷関 数 $\varphi_{\mathrm{dam}}$ を定める. $\varphi_{\mathrm{dam}}$ の関数形の合理的な定め方 が見当たらないので，ここでは $C_{5} ， C_{6}$ を係数とし て以下のように仮定する。

$$
\varphi_{\mathrm{dam}}(Y, d)=\frac{C_{5}}{C_{6}+1}\left(\frac{Y}{C_{5}}\right)^{C_{6}+1}\left(\frac{1}{1-d}\right)
$$

以上より, 塑性乗数玄は, 式(14)とここで定めた 各関数により

$$
\dot{\lambda}=-\frac{(1-d)}{\left(C_{1}+2 C_{2} \beta-C_{4}\left(Y / C_{5}\right)^{C_{6}}\right)}\left(\frac{\sigma_{i j}^{d}}{\sigma_{\mathrm{Y}}}+C_{3} \delta_{i j}\right) \dot{\sigma}_{i j}
$$

となる，式(20)と発展式(11)，(12)より塑性ひずみ速 度と硬化パラメータ速度は,

$$
\begin{aligned}
& \dot{\varepsilon}_{i j}^{p}=\dot{\lambda} \frac{\partial f}{\partial \sigma_{i j}}=\frac{\dot{\lambda}}{1-d}\left(\frac{\sigma_{i j}^{d}}{\sigma_{\mathrm{Y}}}+C_{3} \delta_{i j}\right) \\
& \dot{\beta}=\dot{\lambda} \frac{\partial f}{\partial B}=\frac{\dot{\lambda}}{1-d}=\sqrt{\frac{\dot{\varepsilon}_{i j}^{p} \dot{\varepsilon}_{i j}^{p}}{1+2 C_{4}^{2}}}
\end{aligned}
$$

となる。また，損傷速度 $\dot{d}$ は式(21)および式(13)よ り次式のように書くことができる。

$$
\dot{d}=\dot{\lambda} \frac{\partial \varphi_{\text {dam }}}{\partial Y}=\frac{\dot{\lambda}}{1-d}\left(\frac{Y}{C_{5}}\right)^{C_{6}}
$$

ここで定式化した損傷モデルは, ヤング率 $E$ とポ アソン比 $v$ の 2 つ弾性係数, $C_{1} \sim C_{6}$ の 6 つの係 数を定めることにより確定するが，これらの定数を どのように合理的に定めるかが問題となる.

\section{2 係数の同定と結果の比較}

ここでは，前節で定式化した損傷モデルの各係数 の同定法について述べるが，3. で示した図-6の地 盤材料解析モデルの 2 軸せん断載荷シミュレーショ ン試験を対象とする。

まず，ヤング率とポアソン比は，応力ひずみ曲線 の初期状態の傾きから求めることができる.

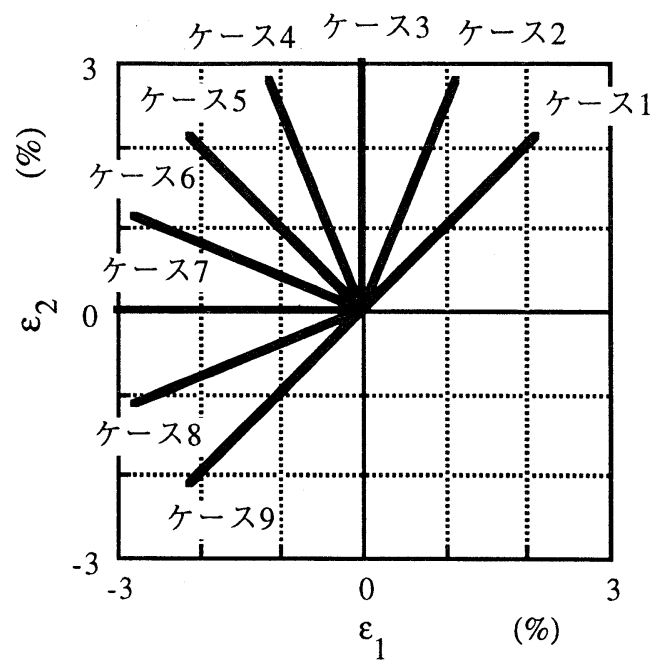

図-10＼cjkstart主ひずみ空間における載荷経路

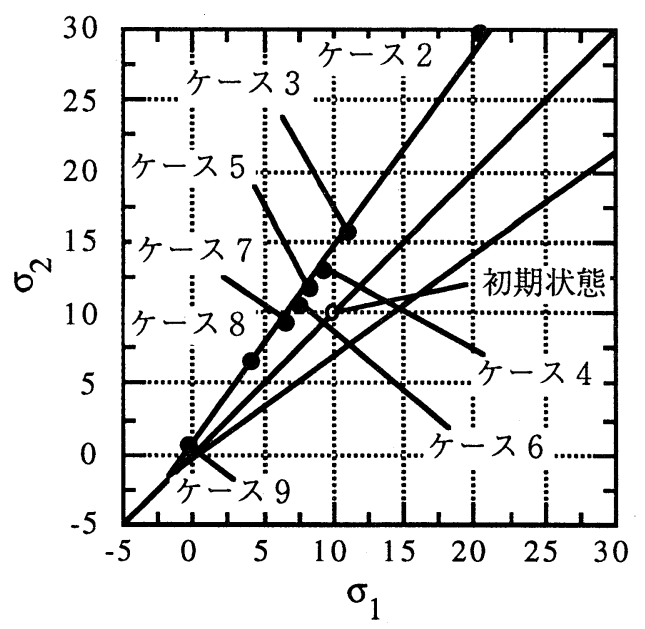

図-11 主応力空間上の初期降伏曲線

次に, 降伏関数 $f$ の係数 $C_{3}, C_{4}$ は, 対象として いる地盤材料解析モデルに対して様々な方向に載 荷・除荷試験を行うことで求めることができる。こ こでは, 図-10に示す 9 通りの載荷経路で載荷シ ミュレーション試験を行った. 前章でで示した 2 軸 せん断載荷シミュレーション試験は, 図-10におけ るケース 5 の載荷経路に相当する。載荷シミュレー ション試験により得られた各載荷経路の初期損傷が 発生した時の応力を主応力空間上にプロットすると 図-11のようになる。同図より，これらの点が主応 力空間上にほほ直線に並ぶことから, Drucker-Prager 型の降伏関数がほぼ妥当であることが示され，さら に, この直線の傾きから係数 $C_{3}, C_{4}$ を定めること ができる。

損傷関数 $\varphi_{\mathrm{dam}}$ に関する係数 $C_{5}, C_{6}$ に関しては, 載荷シミュレーション試験より得られる損傷パラ メータとひずみの関係および除荷した際の弾性変形 の 2 つの情報を基に定められる. 従来の実験などで は, 材料内部の構造欠陥の様子を定量的に評価する ことができないため, 多くの損傷モデルでは応力ひ ずみ曲線をカーブフィッティングして係数を決め, 
損傷パラメータの変化はそれに従属して得られるも のでしかない。しかし, 載荷シミュレーション試験 を行うことにより，内部の構造欠陥か図-7のように 視覚的にとらえられるだけでなく，具体的に損傷パ ラメータを定義すれば図-8のようにその変化の様子 を示すこともできる. また, 同一のモデルに関して 載荷途中の様々な点から除荷試験を行うこともで き, 構造欠陥の発生・発展に伴う弾性係数の变化を 観察することができる。したがって，損傷関数に関 する係数を直接的に決定することが可能となる.

3. で述べた載荷シミュレーション試験とここで示 した損傷モデルの各々の損傷パラメータの変化の様 子を図-12に示す。これより, 損傷の発展がほほ載 荷シミュレーション試験と合致していることがわか る. また, 初期損傷の発生点もほぼ一致し, 降伏基 準が正確に表現されていることも伺える.

最後に, Gibbsの自由エネルギー関数 $G$ の非弾性 部分に関する係数 $C_{1}, C_{2}$ は, 塑性ひずみの発展に 関する係数であるが，ここでは上述のような方法で 他の 6 つの係数を決定した後, 図-9の応力ひずみ曲 線に最も合致するような值を見出すことにより定め た.

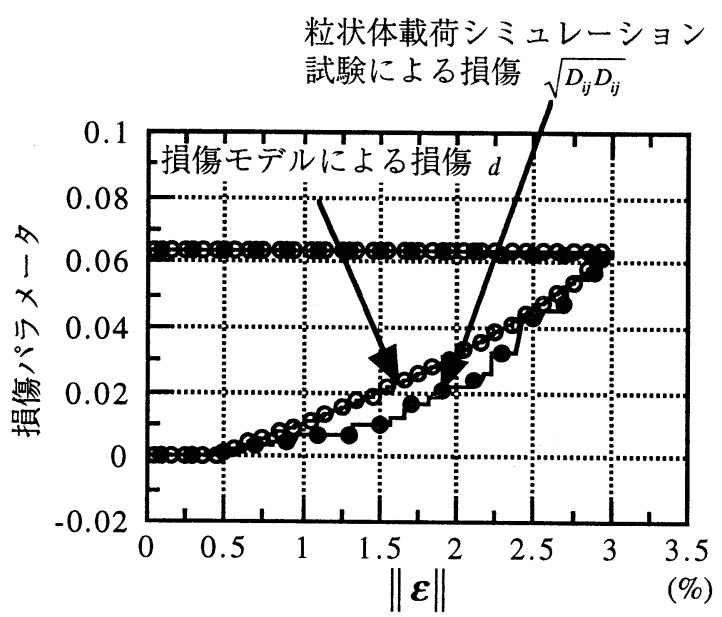

図-12 損傷パラメータの比較（ケース 5 )

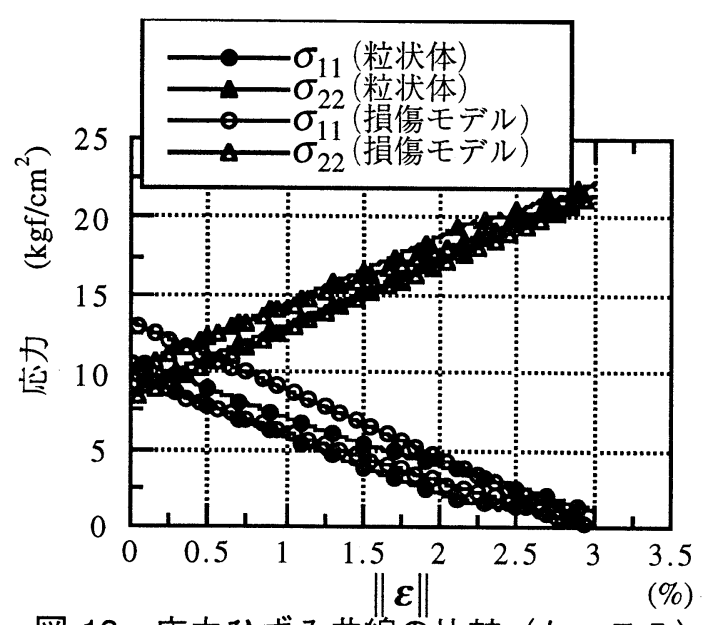

図-13 応力ひずみ曲線の比較（ケース 5 ） 表-2＼cjkstart損傷モデルの各係数值

\begin{tabular}{|c|c|c|c|}
\hline ヤング率 & ポアソン比 & $C_{1}$ & $C_{2}$ \\
\hline 795 & 0.2 & -2400 & 85000 \\
\hline$C_{3}$ & $C_{4}$ & $C_{5}$ & $C_{6}$ \\
\hline-0.223 & -0.119 & -0.001 & 0.4273 \\
\hline
\end{tabular}

ここで求めた各係数の值を表-2に示し，応力ひず み曲線を図-13に示す．図-13より応力ひずみ曲線 は, かなり正確に載荷シミュレーション試験結果を 表していることがわかる。

以上のように，スカラー損傷パラメータを用いた 簡単な損傷モデルでもケース 5 の載荷経路に関して 係数が適切に定められ, 載荷シミュレーション試験 が精度良く表現されている。次節では，このように 定めた係数を用いて, 図-10に示す他の載荷経路に 対して載荷シミュレーション試験結果と損傷モデル による計算結果を比較し, 定式化した損傷モデルお よびその定数に関する検証を行う。

\section{3 損傷モデルの検証}

ここでは，ケース 1 , ケース 3 ，ケース 7 ，ケー ス 9 について損傷パラメーターひずみ曲線および応 カーひずみ曲線を比較する（図-14〜図-17）。な お，応力ひずみ曲線の凡例は，図-13の凡例と全て 同じである。

図-14には, ケース1の載荷経路についての結果 を示したが，等方 2 軸圧縮経路であるので損傷，塑 性ひずみ共に発生せず， $x_{1} ， x_{2}$ 方向とも同じょう に変形する，損傷モデルにおいても損傷，塑性ひず みは発生しておらず応力ひずみ曲線は線形になる。 損傷モデルは，弾性係数のみに依存することとなる が, 前節で定めた弾性係数が, 地盤材料解析モデル の弾性係数を正確に表していることがわかる.

図-15〜図-17の(a)は，各ケースの損傷パラメータ の変化の様子を比較しているが, 全てのケースにお いて, 最初に損傷の発生する点は載荷シミュレー ション試験と損傷モデルとがほほ一致している。し たがって，ここで定めた損傷モデルの初期降伏基準 は, 地盤材料解析モデルの初期降伏基準を精度良く 表しているといえる。また，全てのケースにおいて $\|\boldsymbol{\|}\|$ が $1.5 \%$ 付近までは損傷の発展の様子をほほ正確 に表している。しかし，その後の損傷の発展に関し ては，かなり異なる結果となっている。ここで， ケース 2 ケース 9 の載荷シミュレーション試験と 損傷モデルの損傷パラメータの最大值を比較し, 図18に示す．載荷シミュレーション試験の結果では, ケース 6 が損傷パラメータが最も大きくなる載荷経 路であり，ケース 5 よりもケース 7 の方が大きくな ることがわかる．微視的に見れば，粒子間の結合の 


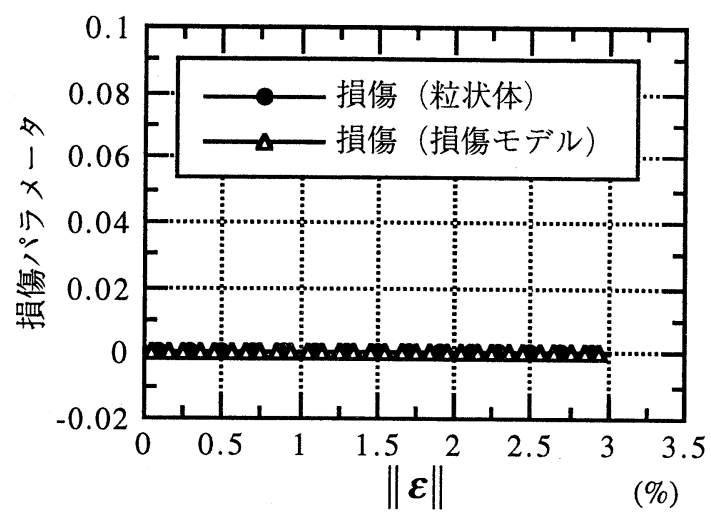

(a) 損傷パラメータの比較

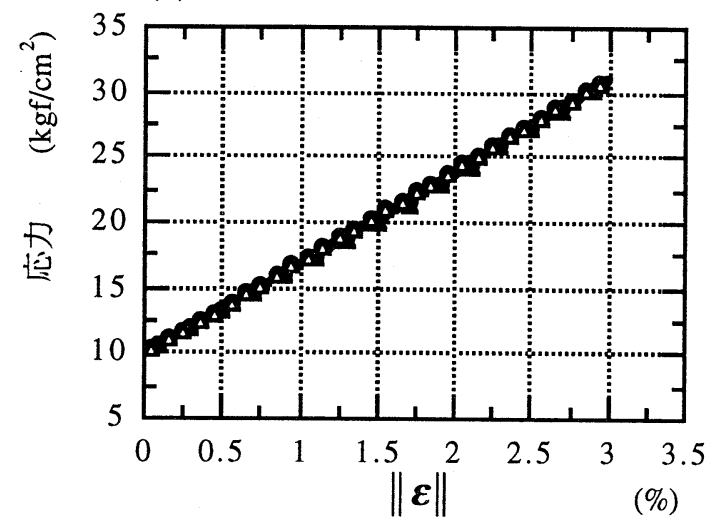

(b) 応力ひずみ曲線の比較

図-14 粒子シミュレーション試験と 損傷モデルの比較（ケース1)

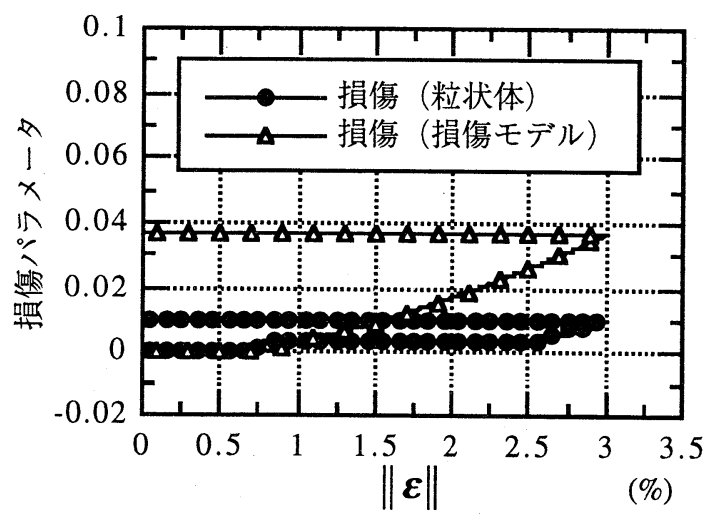

(a) 損傷パラメータの比較

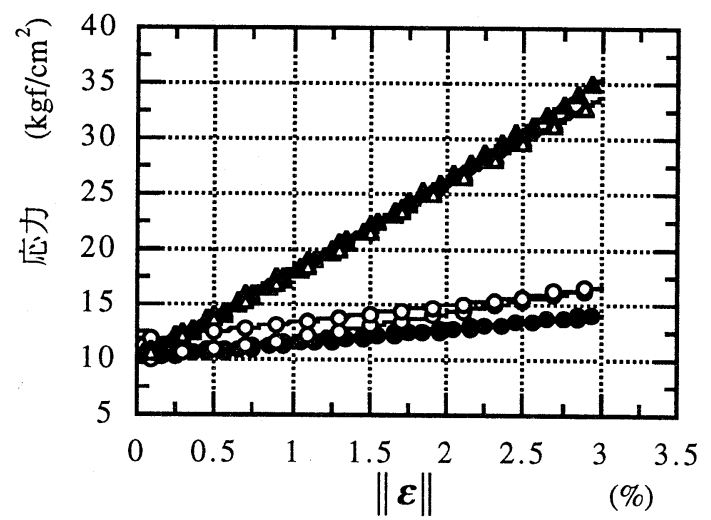

(b) 応力ひずみ曲線の比較

図-15粒子シミュレーション試験と 損傷モデルの比較（ケース3）

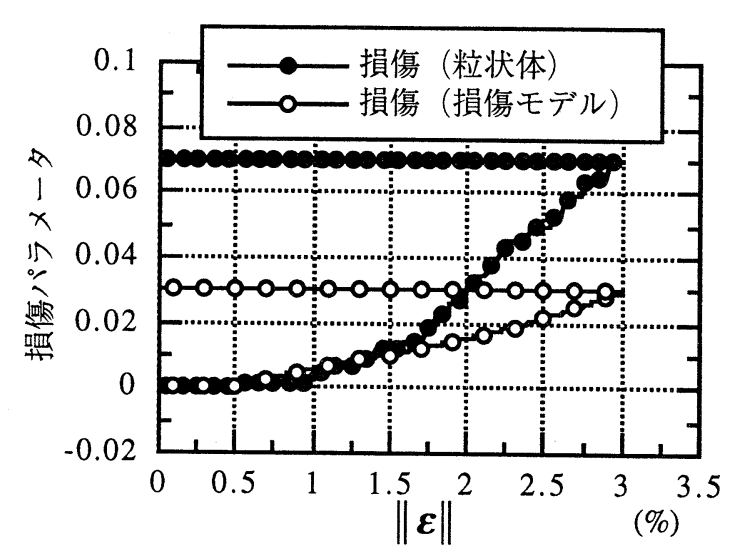

(a) 損傷パラメータの比較

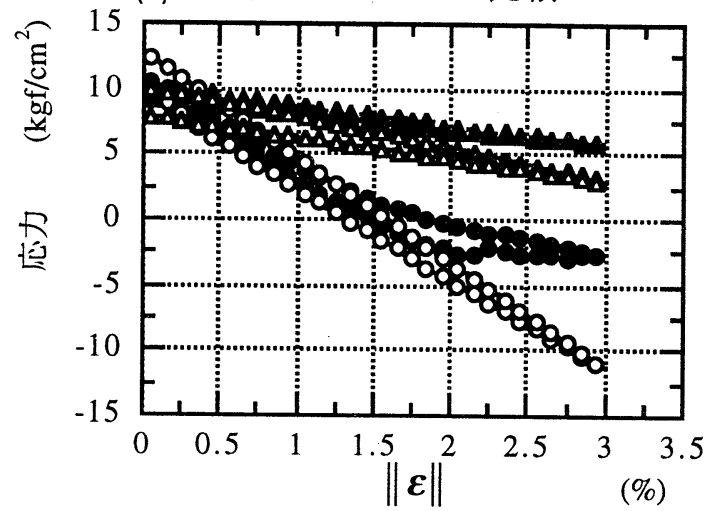

(b) 応力ひずみ曲線の比較

図-16 粒子シミュレーション試験と 損傷モデルの比較（ケース７）

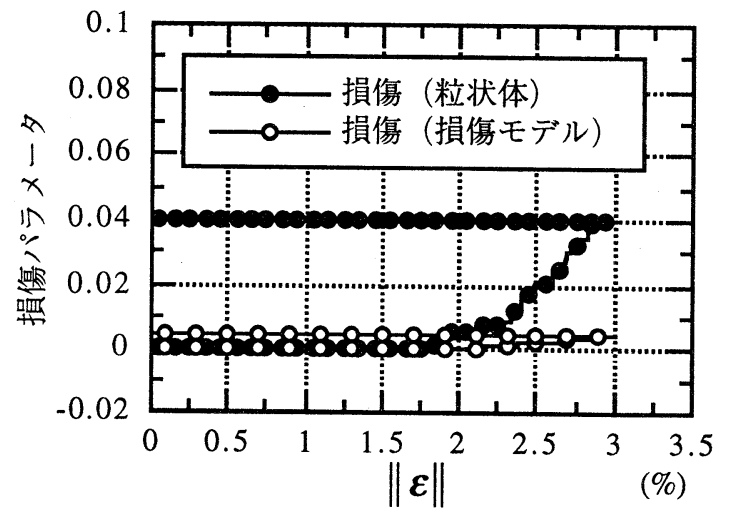

(a) 損偒パラメータの比較

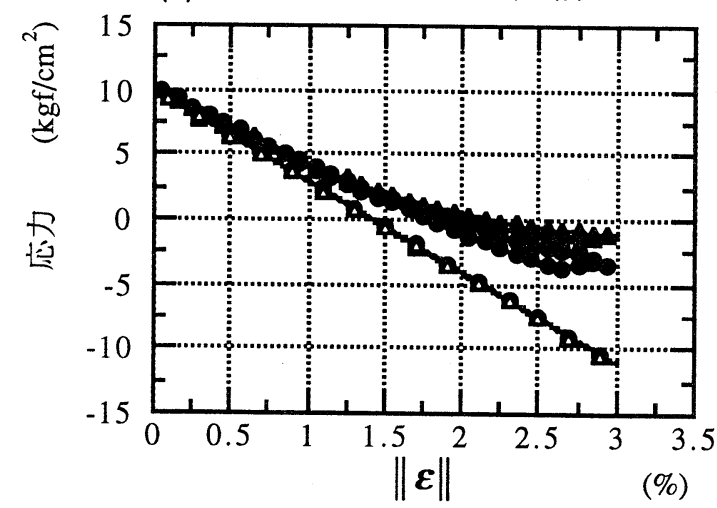

(b) 応力ひずみ曲線の比較

図-17 粒子シミュレーション試験と 損傷モデルの比較（ケース9） 


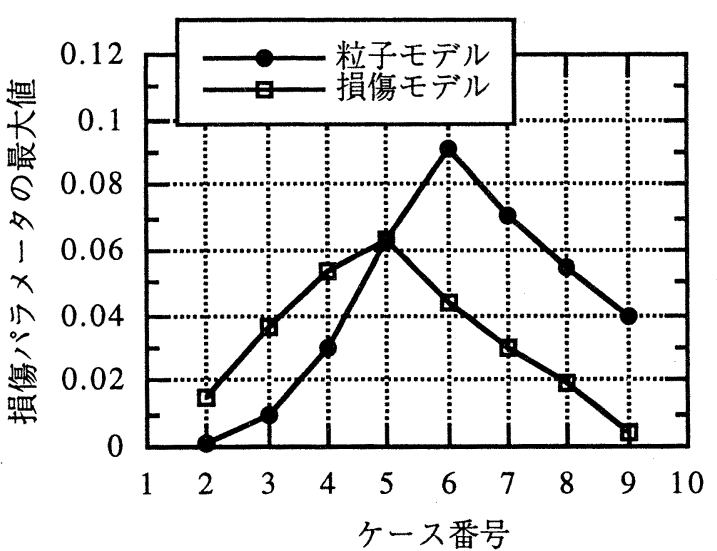

図-18 各ケースの損傷パラメータ最大值の比較

解消が圧縮では生ぜず引張りに対して発生するた め，ケース $6 ， 7$ の巨視的に引張りモードが卓越す る載荷経路において最大の損傷が発生する.ケース 9 においては，両方向に引張りであり損傷の増加は 急激であるものの, 損傷が最初に発生する点がケー ス 6，7よりも遅いため最大值は小さくなる．損傷 モデルの損傷パラメータは，式(21)で示した損傷関 数に依存するが，ここで定めた関数形㧍よびケース 5 を基準として定めた定数では，上述したような全 ての載荷経路に関して適切に材料内部の損傷を表す ことはできない，特に，最大の損傷を生ずる載荷経 路がケース 5 であり, ケース 6 よりもケース 4 の方 が大きな損傷を発生するのは，非現実的であると思 われる。損傷関数に関しても，載荷シミュレーショ ン試験から得られる微視的な情報をより反映して定 める方法を工夫する必要があるであろう。

図-15(b)は，ケース 3 の応力ひずみ曲線の比較を 示している. 損傷モデルを初期状態まで除荷した場 合に， $\sigma_{11}$ が初期状態より大きくなることがわか る。これは，塑性ひずみの大きさに対して損傷パラ メータの大きさが非常に大きいことを意味し, 損傷 パラメータが, 載荷シミュレーション試験よりも大 きく評価されているためである．また， $\sigma_{22}$ に関し てはかなり適合しているが, $\sigma_{11}$ は多少のズレが生 じている。このことは, 損傷パラメータをスカラー として定義している影響であり，材料内部の損傷の 大きさだけでなくその方向が巨視的な変形機構に影 響を及ほすすため，スカラー量の損傷パラメータによ る損傷モデルではその挙動を完全に表現することに は無理があるであろう.しかし，本文においては， 実際の試験では求めることのできない損傷を求め, 少なくとも指定した載荷経路においては理論に適合 した応力ひずみ曲線を求めることができ，また，他 の載荷経路に対してもある程度応力ひずみ曲線を子 測し得ることを示した。このことは損傷テンソルを 用いた適切な定式化により, より精度の高い構成則 を誘導することが可能であることを示唆している。
図-16のケース 7, 図-17のケース 9 の応力ひずみ 曲線においてもケース 3 の場合と類似した結果が示 されているが, 特に応力が負の值（引張り）となっ た場合にそのズレは顕著になる。一般に地盤材料は 圧縮下において用いられる材料であり，応力が引張 りになる場合には工学的な意味をもたない。した がって, 応力が正值（圧縮）である部分に関しては 本損傷モデルが有効であり，載荷シミュレーション 試験結果との適合性も高い. しかし, 引張り応力が 生じる部分については非現実的な適用であることに 注意する必要がある。

以上より, 本研究で定式化した損傷モデルは, 損 傷関数の定め方や損傷パラメータの選定などに改良 の余地があるが，粘着力を有する地盤材料に対して 有用な基本的モデルとなり得ることを示すことがで きた。

\section{5. おわりに}

本論文において，まず，粘着力を有する地盤材料 の微視的変形機構の解明のために従来の粒状要素法 に粘着力を導入し, 境界条件に依存しない地盤材料 固有の力学特性を調べるための周期境界制御粒状要 素法を開発した。次に, 応用例により本解析手法が 一般的な地盤材料の微視的変形機構の解明に有用で あることを示すとともに，地盤材料内部の粒子間の 結合が解消される過程を損傷パラメータにより定量 的に評価可能であることを示した．さらに，損傷パ ラメータを内部パラメータにもつ数理的構成則とし て一つの損傷モデルの定式化を行い, 載荷シミュ レーション試験結果に照らしてその適用性について の検証を行った。ここで定式化した損傷モデルは, スカラー損傷パラメータと塑性ひずみの 2 つの内部 変数を用いた最も単純なモデルであるが, 本モデル が材料内部の損傷メカニズムを一定のレベルまで反 映するものとなっている．したがって，損傷パラ メータにテンソル量を導入することなどにより, 粘 着力を有する地盤材料の一つの理想的な構成モデル の誘導が可能になるのではないかと考えられる.

\section{参考文献}

1) Kachanov, L. M. : The theory of creep, English translation (by A. J. Kennedy). Nat. Lending Lib. Boston, 1958.

2) Murakami, S. and Sanomura, Y. : Creep and creep damage of sopper under multiaxial states of stress, Plasticity Today : Modeling, Methods and Applications, Elsevier, London, pp.535-551, 1985.

3) Lemaitre, J. : A continuous damage mechanics model for ductile fracture, J. Eng. Materials and Technology, 107, pp.83-89, 1985. 
4) Chaboche, J. L. : Continuum damage mechanics-I : General Concepts, Trans. ASME J. Applied Mechanics, 55, pp.59-64. 1988.

5) Chaboche, J. L. : Continuum damage mechanics-II : Damage growth, crack initiation, and crack growth, Trans. ASME J. Applied Mechanics, 55, pp.65-72, 1988.

6) Krajcinovic, D. : Damage mechanics, Mechanics of Materials, 8, 97-117, 1989.

7) 京谷孝史：不連続性岩盤の力学特性評価におけ る損傷力学の適用に関する基礎的研究, 名古屋 大学博士学位論文, 1989.

8) Dragon, A., Cormery, F., Desoyer T. and Halm, D. : Localized failure analysis using damage models, Localisation and Bifurcation Theory for Soils Rocks, (eds, Chambon, Derues, Vardoulakis), Beikema, Rotterdam, pp.127-140, 1994.
9) Cundall, P. A. and Stack, O. D. L. : A discrete numerical model for granular assemblies, Geotechnique, Vol.1, No.2, pp.293-298, 1973.

10) 岸野佑次 : 新しいシミュレーション法を用いた 粒状体の準静的挙動の解析, 土木学会論文集, Vol. 406/III-11, pp.97-106, 1989.

11) 武建勲, 岸野佑次, 京谷孝史 : 改良粒状要素法 による粒状体の断塑性挙動の研究, 構造工学論 文集, Vol. 43A,pp.403-412, 1997.

12) Maugin, G. A. : The Thermomechanics of Plasticity and Fracture, Cambridge University Press, 1992.

13) Cauvin, A. and Testa, R. B. : Elastoplastic material with isotropic damage, Int. J. Solids and Structure, Vol.36, pp.727-746,1999.

（1999 年 4 月 23 日受付） 